\title{
Global Value Chain in Agro-export Production and Its Socio-economic Impact in Michoacán, Mexico
}

\author{
L. Crespo Stupková
}

Michoacán's College, Center of Human Geography Studies, Mexico

\begin{abstract}
Mexican blackberry production is very geographically concentrated in the Valley Los Reyes, where most of blackberries, which the country exports, are produced. Taking into account that Mexico is the world's largest exporter of this fruit in terms of quantity; we can conclude that a relatively small area produces most of the blackberries that are traded worldwide. The paper aims to analyze the blackberry value chain and its local socio-economic impact. The main conclusion is that the global value chain of blackberries brings benefits for the small farmers and investors too, but it is necessary establish contract terms ensuring that contractors do not abuse their market power. Also it was demonstated the positive local socio-economic impact of the activity.
\end{abstract}

\section{Keywords}

Global value chain, blackberry, socio-economic impact, Michoacán, contract farming.

Crespo Stupková, L. (2016) "Global Value Chain in Agro-export Production and Its Socioeconomic Impact in Michoacán, Mexico", AGRIS on-line Papers in Economics and Informatics, Vol. 8, No. 1, pp. 25 - 36. ISSN 1804-1930, DOI: 10.7160/aol.2016.080103.

\section{Introduction}

The actual global economy is formed by global value chains (GVCs) which are embedded within local economic, social and environmental dynamics and the insertion in the GVC depends significantly on these local conditions. Economic conditions include the availability of key inputs: labor costs, available infrastructure and access to finance; social context governs the availability of labor and its skill level, such as female participation in the labor force and access to education (Gereffi and Fernandez-Stark, 2011); and finally environment includes biological, chemical and physical factors, biotic or abiotic (like ambient temperature, sunlight, $\mathrm{pH}$ of the water or soil).

The World Hunger Report estimates that the world's poor fall into roughly three categories.

About $60 \%$ are small farmers and pastoralists, $20 \%$ are landless rural laborers and nonfarm entrepreneurs, and the remaining $20 \%$ urban poor. The principal resource of the rural poor is unskilled labour (Haggblade et al., 2012). The concepts of social and economic upgrading are important factors within global value chains because they contribute to more sustainable growth and development: stimulates innovation, promotes employment based on decent work and respect for labour standards (Gereffi and FernandezStark, 2011). Work to promote market linkages in developing countries is often based on the concept of "inclusive value chains", which usually places emphasis on identifying possible ways in which small-scale farmers can be incorporated into existing or new value chains or can extract greater value from the chain, either by increasing efficiency or by also carrying out activities further along the chain (Haggblade et al., 2012). Different public and civil society actors have to work together with the private GVC governance and global lead firms to complement each other and lead to synergistic governance. Policy interventions for sustained poverty reduction require use of GVCs as a policy tool: to generate better employment, enhance skills and knowledge, improve labour conditions and raise incomes.

It is supposed that the foreign investments in developing countries increase private standards in GVCs. Quality standards, such as GLOBALGAP (Good Agricultural Practice), have become critical in GVCs as a number of firms in different countries affect the quality of final products (Lee and Gereffi, 2015). Global lead firms are increasingly facing public pressure to make their supply chains socially and environmentally sustainable (Nadvi, 2014). 
Actually the developing country firms tend to be portrayed as 'standard-takers' but it is desirable that they initiate their own effort to improve working conditions, for example collectively within clusters. In agro-food chains, large food manufacturers and supermarkets are increasingly rationalizing their supply chains to work directly with a smaller number of preferred, mostly large, suppliers capable of meeting their stringent requirements, thereby marginalizing smallholders unable to comply the standards (Maertens and Swinnen, 2009).

According to Hecksher - Ohlin theory, trade among regions and countries results from differences in relative endowments of the factors of production (labour, land and capital). This theory explains that each country will export those goods whose production is relatively intensive in the country's abundant (and therefore cheap) factor (Berry et al., 1997; Knox and Agnew, 2002). Thus, Mexico has large supplies of cheap labor and therefore concentrates on producing and exporting laborintensive agricultural products like blackberries. Michoacán has natural conditions (favorable climate and soil conditions) for growing fruits which represents a comparative advantage.

In today's globalized world, demand for exotic seasonal fruit increases and the consumers want products available all year long. The Michoacán production of berry is filling the gap (September to May) of the cycle in the Global North. Blackberries are considered as a luxury product that fills North niche markets to meet the demands of affluent consumers (Chollett, 2010).

The blackberry is an edible fruit of the Rubus genus in the Rosaceae family. The fruit has significant contents of dietary fiber, vitamin $\mathrm{C}$, and vitamin $\mathrm{K}$. Common use is in desserts, jams, seedless jelly, juice and candy. The main attributes of blackberry are health-related, so characteristics of odor, color, taste, maturity and presentation are very important. The product must be free of pathogens or residues of chemicals, main reason why the product should comply with a series of safety requirements and standards. For blackberry fields, only agrochemicals recommended by SAGARPA (Mexican Department of Agriculture, Rural Development, Fishery and Alimentation) and EPA (US Environmental Protection Agency) can be used (Sanchéz, 2008). The majority of the production is exported in fresh form, only the fruit that does not meet standards is processed by agro-industrial factories in Zamora (town situated 1-hour away from Los Reyes).

As with all agricultural growth, two things appear essential for a successful value chain development: creating the right environment for agriculture and investing in rural public goods. There is a positive correlation of agricultural growth with investment in irrigation, transport infrastructure and other technologies (Wiggins, 2013). Governments have a responsibility to provide essential goods and services, infrastructure, such as rural roads, and agricultural research (Pye-Smith, 2013). In the region of blackberry production the government is improving the road infrastructure to transport the berries which are vulnerable to mistreat. The main completed project is the modernization and expansion of the road linking Jacona and Los Reyes. It was initiated in the 2004 with a budget of 200 millions of pesos (Thiébaut, 2009).

The importance of the production of blackberries in the studied region illustrate the production value (in thousands of pesos) of this crop: in Los Reyes, the blackberries production in the last 10 years (2004 - 2014) represented on average 55.19\% of the total annual agricultural production value and in Peribán it is $23.90 \%$. The production of blackberries increased in Los Reyes in terms of value more than 8 times in the last 10 years and in Peribán more than 7 times. The planted area and the production in tons increased in the same period 6 times in Los Reyes and 5 times in Peribán. There is no other economic activity with such a high dynamics in the region.

Although the importance of the topic, the number of studies on the blackberries value chain and its socio-economic local impact is small. So the purpose of this paper is to evaluate the global value chain of blackberries and measure the local socio-economic impact of this activity.

The research focused on the evaluation of the global value chain of blackberries, its importance and operating, and the analysis of the possible social and economic impact of the activity.

It aims to answer the following main research questions:

- How is operating the global value chain of blackberries?

- What local impact does the GVC have on income and rural development?

\section{Materials and methods}

A combination of research tools was applied to achive the goal. In the first step a literature 
review of oficial documents and academic works was conducted. Successively, descriptive stastics, t-test and geografic indicator for the evaluation of the economic concentration were applied to analyze the socio-economic data. The sources of oficial data used for the research were Mexican National Institute of Geography and Statistics, Mexican Agricultural and Fishery Information Service, United Nations Development Programme, United Nations Conference on Trade and Development, International Trade Center, The Organization for Economic Co-operation and Development, World Trade Organization and World Bank Group. Data processing software was used, specifically SPSS (Statistical Package for the Social Sciences).

For the evaluation of the global value chain of blackberries it was used indicators of the involvement of the Mexican economy into the global market: Foreign Value Added, Domestic Value Added and GVC Participation Rate; the importance of the international trade with fresh berries (measured by indicators of Main World Exporters, Importing Markets for Mexican Fresh Berries and Supplying Markets for Fresh Berries Imported by United States of America); the geographic scope indicators (Concentration of Production in Michoacán State and specially in Los Reyes Valley) and government patterns in the chain.

The local economic and social impact can be measured in different ways. One possibility is Human Development Index (HDI) which was created by UNDP (United Nations Development Programme) to emphasize that people and their capabilities should be the ultimate criteria for assessing the development of a country, not economic growth alone. Its dimensions are: Health (Life Expectancy at Birth Component), Education (Mean of Years of Schooling for Adults Aged 25 Years and Expected Years of Schooling for Children of School Entering Age) and Income (Gross National Income per Capita). All the parameters of HDI for municipalities Los Reyes and Peribán were tested by the onesample $t$ test to confirm if the population mean (for all 113 municipalities of Michoacán state in years 2000, 2005 and 2010) coincides or no with the values for these municipalities which produce blackberries. It was applied one-sided test at significance level $\alpha=0.01$.

Another possibility how to measure the economic impact of the activity is the use of the indicator of the Economic Concentration per Capita. This indicator takes into account the value of Total
Gross Production of primary, secondary and tertiary sectors and Total Population of the municipality (Palacio-Prieto and Sanchéz-Salazar, 2004). It is presented in thousands of pesos and the data are for 2008 (last published results of statistical census at municipality level for the three sectors). The sample is 113 municipalities of Michoacán state and the year 2008 .

$$
\mathrm{CCE}=\frac{\text { TGPS }}{\text { TPM }} \text { (thousands of pesos per capita) }
$$

Where: TGPS $=$ Total Gross Production of Agricultural, Livestock and Forestry Production, Fishing and Mining; Manufacturing, Electricity and Water Production, Construction Industry; Transport, Communications, Trade and Services and TPM $=$ Total Population of the Municipality.

The Gross National Income per capita in 2010 is also mentioned for comparison (the sample of 113 municipalities as well).

The quality of life of the population depends on the conditions of housing, therefore has been included in the analysis the indicators of household living standards: Household

Facilities (piped water and drainage) and Household Equipment (washing machine, fridge, earthen floor). All the indicators of 113 municipalities of Michoacán state in years 2000, 2005 and 2010 were tested by the one-sample $t$ test to confirm if the population's mean coincides or no with the values for municipalities Los Reyes and Peribán.

Given the importance of the women participation in the economic activities, it was included in the analysis the Women Employment Rate and the Total Employment Rate (INEGI data, 2010 for 113 municipalities of Michoacán).

\section{Results and discussion}

The results are divided in two parts, each focused on response one of the main research questions - characterization of the GVC of blackberries and its economic and social impact.

1. Characteristics of global value chain of blackberries in Mexico

For determining of the GVC and its operation it is necessary to outline the general economic environment where the activity develops, so it is included the chapter of Mexican participation in globalization and the international trade with fresh berries. Then it is targeted the specific 
case of the blackberries value chain in Michoacán.

\subsection{Mexican Participation in Global Value Chains}

The topic of the participation of developing countries in the globalization process and the advantages and disadvantages of engaging in the GVCs is frequently discussed (Gereffi and Fernandez-Stark, 2011; Lee and Gereffi, 2015; Lee et al., 2011; Eaton and Shepherd, 2001; Humphrey and Schmitz, 2000). Inspecting the official data, it is obvious that the share of global value added trade captured by developing economies is increasing rapidly. It grew from around $20 \%$ in 1990 , to $30 \%$ in 2000 , to over $40 \%$ in 2010 (UNCTAD, 2013). Estimated benefits for Mexico from trade facilitation between 2007 (baseline) and 2014 were $14 \%$ for the volume of non-oil and gas exports, $32 \%$ for the volume of non-oil and gas imports, and $7 \%$ for the gross domestic product (Tsigas and Ferrantino, 2014).

The main indicators, which recognize the World Investment Report of Global Value Chains to measure the involvement of the local economy into the global market, are Foreign Value Added, Domestic Value Added and GVC Participation Rate.

Foreign Value added (FVA) indicates what part of a country's gross exports consists of inputs that have been produced in other countries and it is not adding to its GDP. The highest shares of FVA in trade are found in East and South-East Asia and in Central America (including Mexico) where processing industries account for a significant part of exports. Central America share of FVA in exports was of $31 \%$ in 2010 (higher than the developing counties average).

Domestic Value added trade share is the trade contribution to the GDP of the country and can be significant relative to the size of local economies. In the case of Mexico, the part of exports created in-country was $68 \%$ in 2010 . The agricultural exports form part of the Domestic Value Added, so they have a direct impact on GDP. In the year 2014 the agricultural exports amounted $3.96 \%$ of total Mexican exports (manufacturing exports being the most important category with $80.5 \%$ share). The highest share in agricultural exports in terms of value (millions of USD) has tomatoes (15.64\%), followed by other fresh vegetables (13.71\%), pepper $(12.78 \%)$ and avocado $(12.56 \%)$.

GVC Participation Rate - upstream links (foreign value added in exports) and downstream links (exports that are incorporated in other products and re-exported) - indicates how the country is integrated in international production networks. Depending on the GVC participation of the country we can estimate how much hypothetical damage to GVCs would occur if a country's exports were blocked as well as the vulnerability of the GVC to shocks in an individual economy along the value chain. Mexico has a high participation rate in the upstream component, where it ranks equal with South East Asia. However, it has a lower downstream participation rate, reflecting the fact that it exports relatively more to the United States domestic market rather than for onward exports.

\subsection{International trade with fresh berries}

Mexico is the biggest world exporter of fresh Raspberries, blackberries, mulberries and loganberries ${ }^{1}$ in the terms of quantity: the exportet quantity (tons) was in 2014 of 63,028 (31.1\% of the world exportations) and it is growing up all the years since the 2010. In the 2014 it was 22,404 tons more then 2010 (upsurge of $35.5 \%$ ). However in the terms of value, Mexico is the third after United States of America and Spain, as displayed in Figure 1.

The exports of Mexican fresh berries keep growing since the 2010, the maximum growth rate was achived between 2013 and 2014 (32\%).

The target market of Mexican berries are United States of America, which received $87.9 \%$ of total Mexican exports in 2014. In the European market, exports to United Kingdom, Netherlands and Italy have the highest representation. All the exports are growing, except the exports to United Kingdom (reduction of 2\% between 2013 and 2014). The largest increase occurred in exports to Italy, where it was $50 \%$. Mexico is the second most important exporter of fresh berries to Netherlands and the third most important exporter to United Kingdom, Italy and Belgium (Figure 2).

The importance of the Mexican exports to the US market shows the following figure: $97.1 \%$ of the imported berries come from Mexico; other suppliers are in substance insignificant. The share of Mexico's exports to USA since 2010 is almost constant; nevertheless the values increased more than twice - from 276,113 thousands of US Dollar (in 2010) to 601,912 thousands of US Dollar (in 2014) (Figure 3).

Product class 081020 of the International Trade Center. 


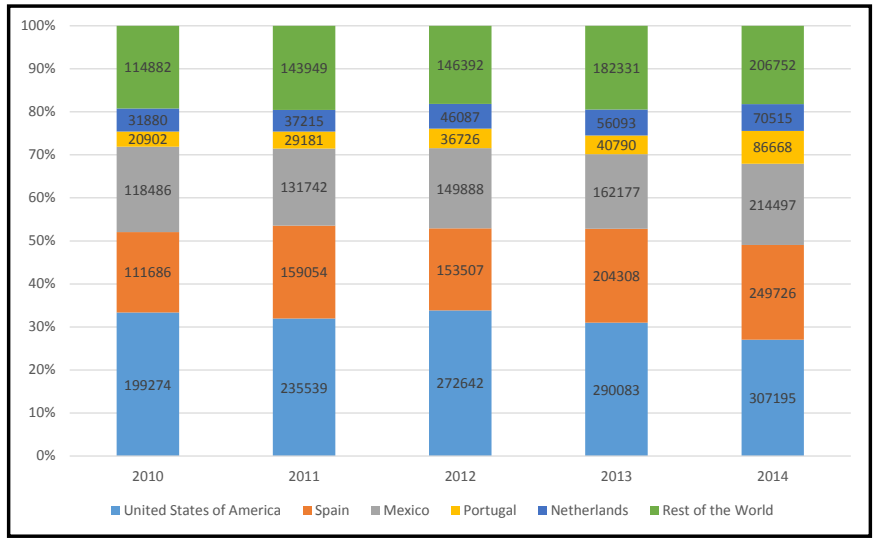

Source: ITC (International Trade Center), 2014

Figure 1: Exporters of fresh raspberries, blackberries, mulberries and loganberries (Thousands of US Dollar)

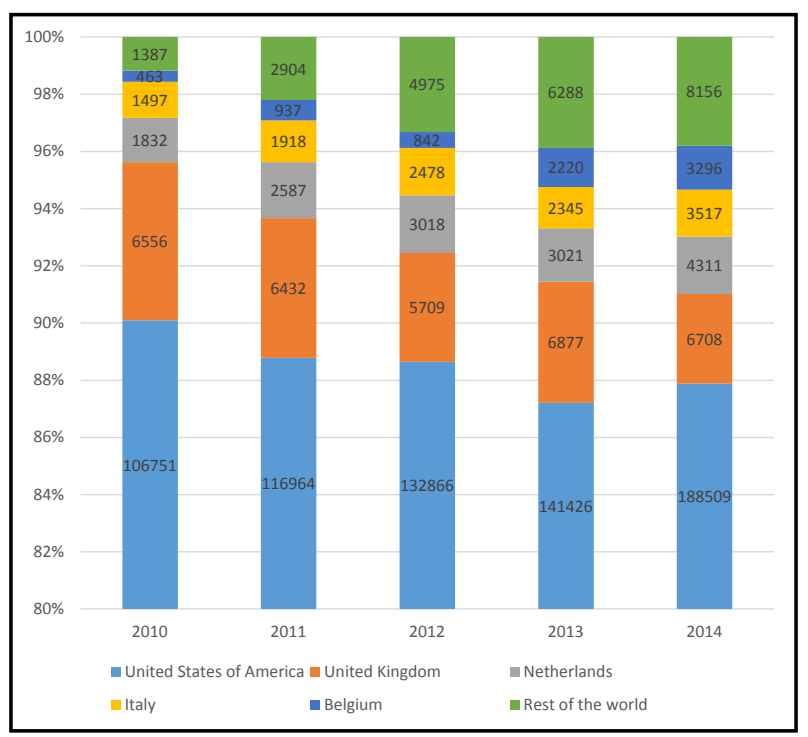

Source: ITC (International Trade Center), 2014

Figure 2: Importing markets for fresh raspberries, blackberries, mulberries and loganberries exported by Mexico (Thousands of US Dollar)

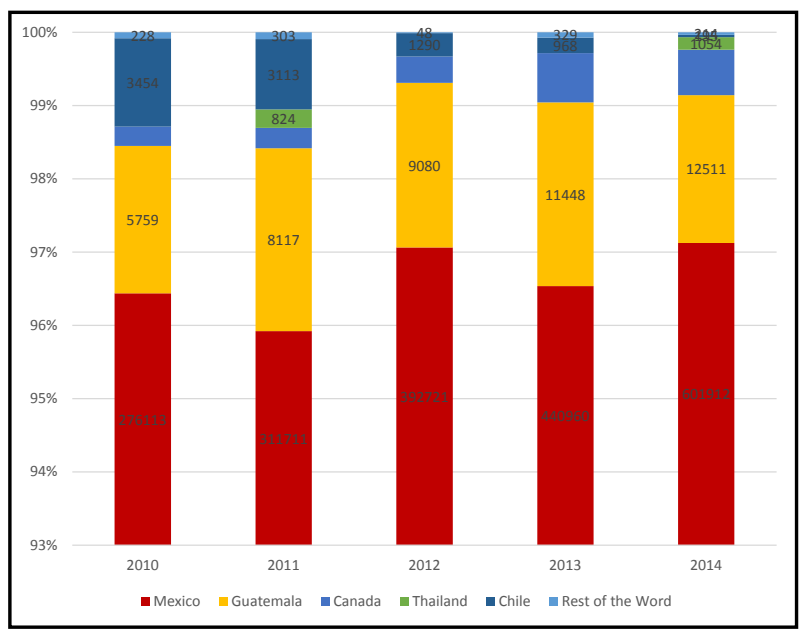

Source: ITC (International Trade Center), 2014

Figure 3: Supplying markets for fresh raspberries, blackberries, mulberries and loganberries imported by United States of America (Thousands of US Dollar). 


\subsection{Geographic Scope of Blackberry Production}

Ninety-eight percent of Mexico's blackberries are grown in the state of Michoacán (production value, 2014), specifically in municipality of Los Reyes $(53 \%$ of the state's production value) and Peribán ( $22 \%$ of the state's production value). The blackberries expanded rapidly in the region: there were approximately 80 hectares in 1995 , 500 in 2001 and 5,000 in 2010. Thanks to their high profitability, blackberries soon began to replace the cultivation of sugar cane (former major local crop). The production of blackberries was 65,260 tons (Los Reyes) and 27,191 tons (Peribán) in 2014 and it grew between 2013 and 2014 in both cases. Whereas the harvested area is practically the same, the increase was due to higher efficiency of production.

The majority of fresh blackberry production is exported to United States. After the completion of NAFTA (North American Free Trade Agreement) the export of fresh fruit to the United States is easier because all the tariffs, permits and antidumping regulations were eliminated. Also transportation of commodities with a very short shelf-life is possible due refrigerated storage facilities and trucks.

\subsection{Governance patterns of the blackberries value chain}

There are different governance patterns of the GVC depending on the degree of power asymmetry and degree of exploit coordination. Berry production forms a vertically integrated chain of production and distribution whose corporate owners rely largely on contract farming ${ }^{2}$. In the case of blackberry agro-export production we can design the GVC like a captive chain. The captive chains (or quasi-hierarchical) is characterized by suppliers with low levels of capabilities, who require high levels of support and are the subject of well-developed supply chain management from lead firms. The suppliers are dependent on one or a few buyers that often wield a great deal of power, control and monitoring. Therefore, the ethical leadership is important to ensure suppliers receive fair treatment and an equitable share of the market price. The lead firms tends to be in areas outside of production and does not encroach on this core competency (through contracting they gain access to the products of the land, since control of land still rests primarily

\footnotetext{
${ }^{2}$ Contract farming can be defined as an agreement between farmers and processing and/or marketing firms for the production and supply of agricultural products under forward agreements, frequently at predetermined prices (Eaton and Shepherd, 2001).
}

in ejidos ${ }^{3}$ ) but helps their suppliers upgrade their production capabilities and so benefit itself by increasing the efficiency of its supply chain. It is estimated that $80 \%$ of companies engaged in the business of blackberry in the domestic and international market are foreign. The costs and risks of production belong to farmers and the costs and risks of transportations and sale belong to foreign companies, the division of competences shows the following graph. The main blackberries companies represent foreign capital investment: Hortifurt, Sun Belle, Expoberries (Chile), Hurst's Berry Farm, Sunny Ridge, Driscoll's (United States), Guimarra/ VBM Berry International LLC (U.S. - Chile joint venture). Mexican companies operating in the sector are Agroindustrial El Molinito, S.A. de C.V., Grupo HerEs and EXIFRUT. All these companies are private, large or medium (Figure 4).

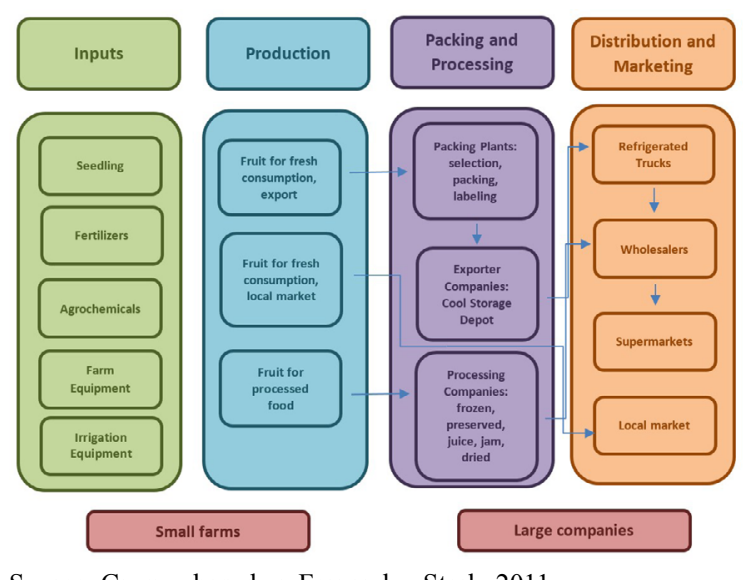

Source: Crespo, based on Fernandez-Stark, 2011

Figure 4: Blackberry Global Value Chain.

The great bulk of agricultural value chains involve sales to companies from independent farmers. Such arrangements frequently involve contract farming in which the farmer undertakes to supply agreed quantities of a product, based on the quality standards and delivery requirements of the purchaser, often at a price that is established in advance. In the 1998 some producers formed an association in response to their vulnerability in relation to foreign companies that determine prices and input requirements. But the foreign exporters did not want to deal with an organized group, and members soon abandoned the association.

\footnotetext{
Area of communal land used for agriculture based on an understanding of the Aztec calpulli.
} 


\section{Economic and Social impact of the blackberry production}

Agro-food involves a relatively large proportion of small scale and low-skill labor-intensive production, particularly at the farm level. As the harvest of blackberries is manual, the manpower needs are important. Workers come from the villages of the Valley Los Reyes and the sierra Purépecha (situated on the north of the Valley). Gradually the area of influence was extended and actually incorporates the villages more than 30 kilometers of the Valley as shown in the following map (Figure 5).

The workers hired for the work on the blackberry fields are often indigenous Purépecha women who are illiterate. Thiébaut (2011) estimate that in the cultivation of blackberry work between 5 and 8 thousands of people and women represent 60 to $70 \%$ of the labor force. Gender implications are important because the work on the blackberry fields represent one of the few opportunities for the women. The companies also prefer to hire women workers; they consider best suited for scrap because it is a delicate work. The profile of a typical worker is a young woman, single and without children. Often teenagers and young adults leave school to earn their own money and gain some independence. These workers are generally mobile and unstable. When the women get married, the majority renounces to work. Other possible profile of worker is older women/widow, often head of households.

Average salaries are 140 pesos per day (6 hours). In rural area this salary is quite high (the daily minimum wage was 66 pesos in 2015). A woman picks 10 boxes (120 containers) per day and each container is sold in the United States for 4 dollars. So we can calculate that the labor cost represents roughly $1.5 \%$ of the price of product.

\subsection{Human Development Index}

It was expected that the economic and social development of the two municipalities (Los Reyes and Peribán) is higher than the mean of the state. As shows the Figure 9, in the 2010 the HDI of Peribán was significantly higher (0.8310) but it does not apply in the case of Los Reyes (0.8091 when the mean of state was 0.8032). Income index was significantly higher in the two municipalities in the 2010, education and health indexes were significantly higher only in the municipality of Peribán. Income index is very high in the municipality of Los Reyes $(0.8148$ when the state's mean was 0.7549$)$, this index is derived from the Gross National Income per Capita, which was 13,184 US dollars in 2010 (state's mean was 9,501 US dollars). The trends over time show that Los Reyes as well as Peribán recorded economic growth since 2000 as showed

${ }^{4}$ It represents 7.1 US dollars (official exchange rate of Bank of Mexico, 9 September 2015).

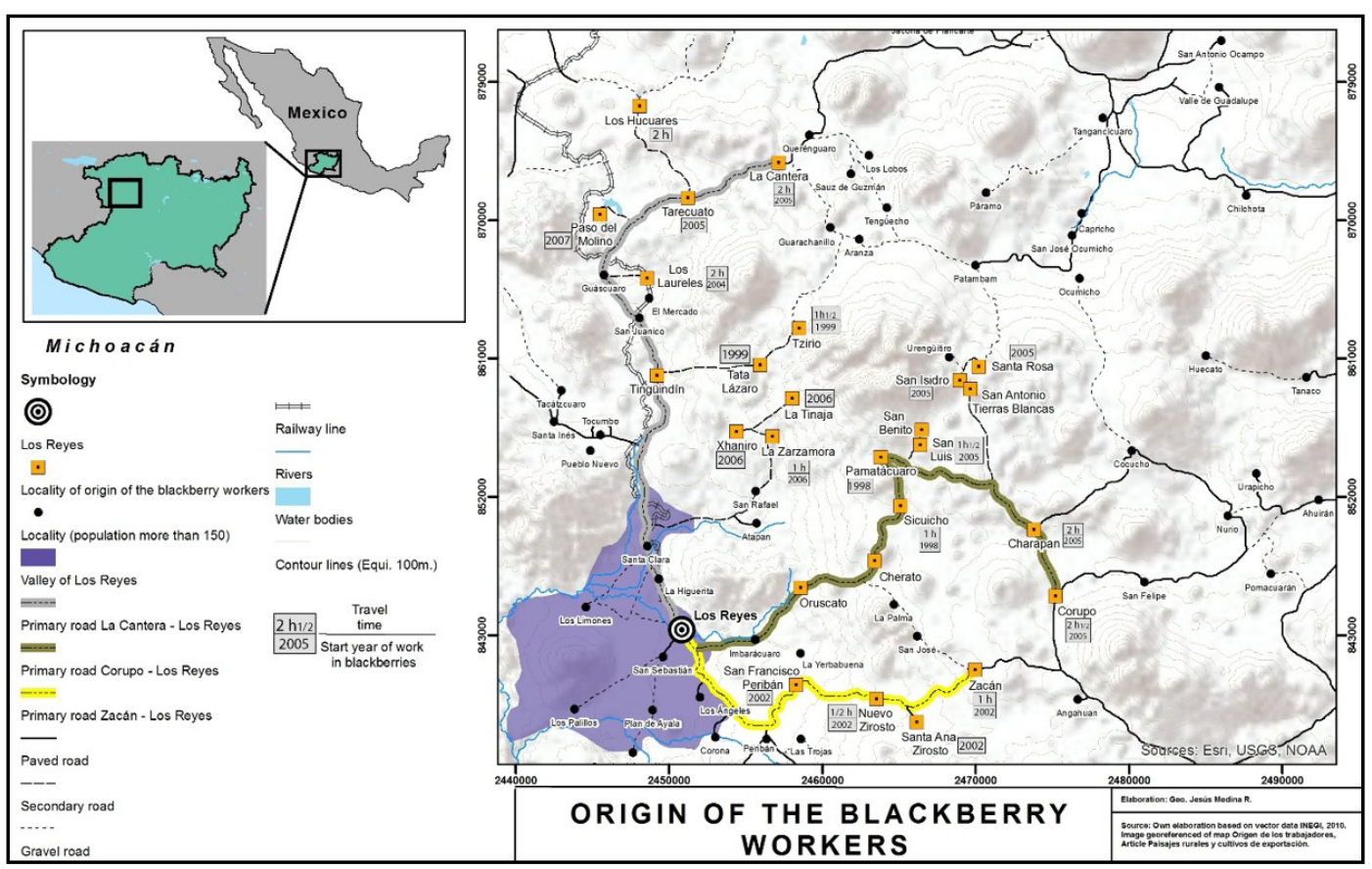

Source: Own elaboration based on vector data INEGI 2010

Figure 5: Origin of the Blackberry Workers. 


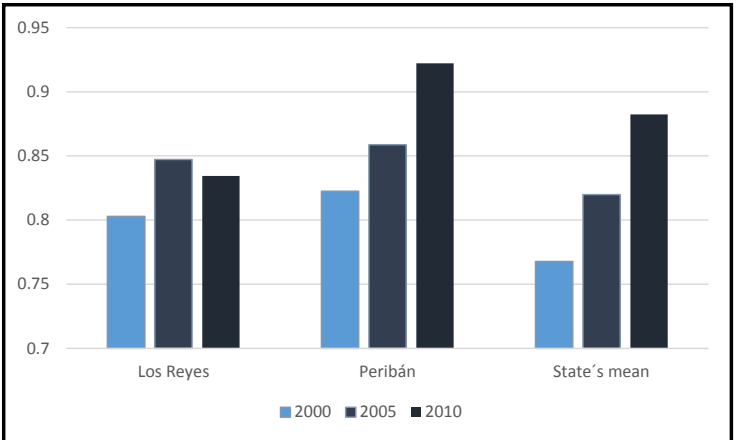

Source: Own elaboration based on UNDP data (HDI 2000, 2005, 2010)

Figure 6: Health Index.

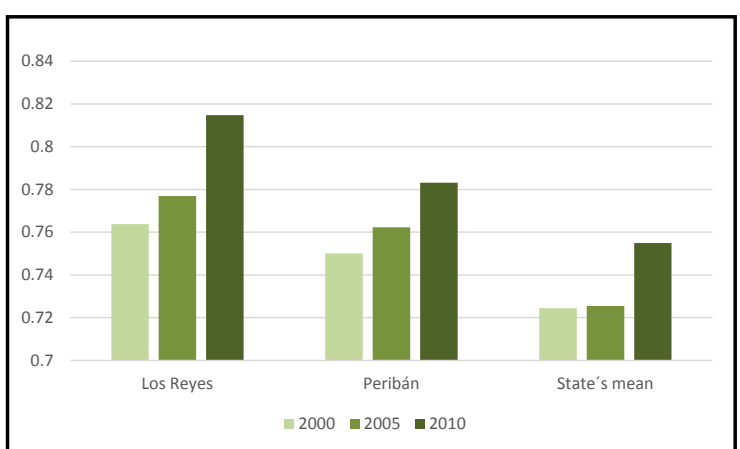

Source: Own elaboration based on UNDP data (HDI 2000, 2005 2010)

Figure 8: Income Index.

in figure 8. The positive social development in the dimensions of education and health was also confirmed (except health index in Los Reyes, which decreased between 2005 and 2010 and was lower than the state's mean). The figures 6 and 7 show the trends in time.

\begin{tabular}{|l|c|c|c|}
\hline Indicator & Los Reyes & Peribán & $\begin{array}{c}\text { Michoacán } \\
\text { State's Mean }\end{array}$ \\
\hline HDI & 0.8091 & $0.8310^{*}$ & 0.8032 \\
\hline Income Index & $0.8148^{*}$ & 0.7831 & 0.7549 \\
\hline Education Index & 0.7780 & $0.7875^{*}$ & 0.7725 \\
\hline Health Index & 0.8345 & $0.9222^{*}$ & 0.8823 \\
\hline
\end{tabular}

Source: Own elaboration based on UNDP data (HDI 2000, 2005, 2010)

Table 1: HDI and its components (2010)

\subsection{Economic Concentration per Capita Index}

The indicator was significantly higher at the significance level $\alpha=0.01$ in both municipalities in 2008 (Peribán 92.5, Los Reyes 51.8, state's mean 26.8 thousands of pesos per capita). The result is very significant at the state's level: Peribán is the second municipality with the highest economic

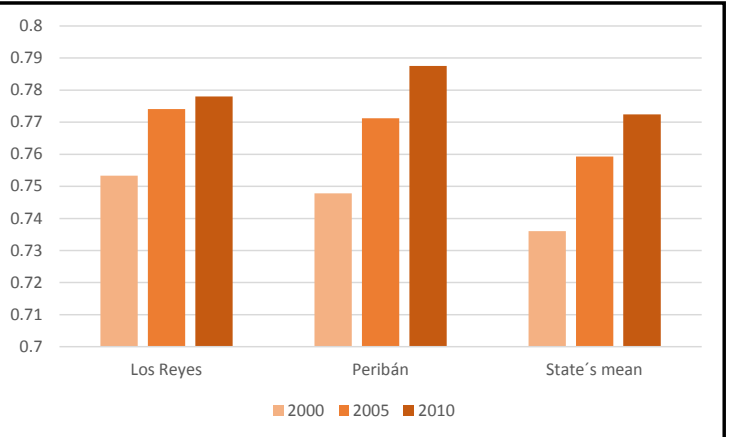

Source: Own elaboration based on UNDP data (HDI 2000, 2005, 2010)

Figure 7: Education Index.

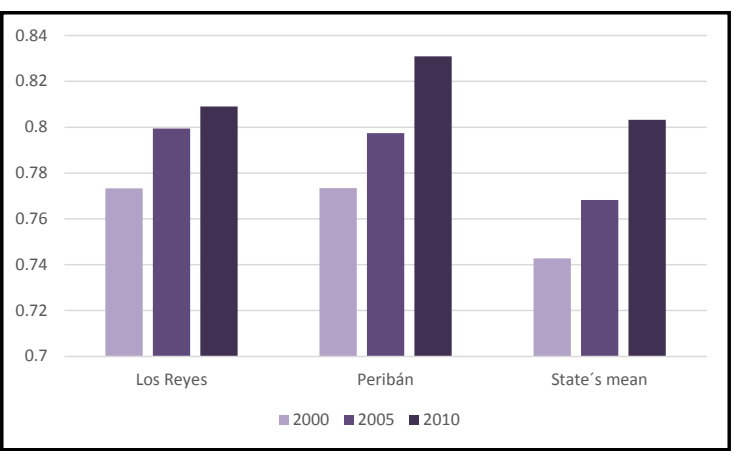

Source: Own elaboration based on UNDP data (HDI 2000, 2005, 2010)

Figure 9: HDI.

concentration per capita of Michoacán (after harbor of Lázaro Cárdenas). Los Reyes is the eleventh municipality of the 113 municipalities of ichoacán. Also the Gross National Income per Capita (US dollars) is very high in Los Reyes and both municipalities are higher than Michoacán average.

\begin{tabular}{|l|c|c|c|}
\hline Indicator & $\begin{array}{c}\text { Los } \\
\text { Reyes }\end{array}$ & Peribán & $\begin{array}{c}\text { Michoacán } \\
\text { State' s Mean }\end{array}$ \\
\hline $\begin{array}{l}\text { Economic Concentration } \\
\text { per Capita (thousands } \\
\text { of pesos) }\end{array}$ & $51.8^{*}$ & $92.5^{*}$ & 26.8 \\
\hline $\begin{array}{l}\text { Gross National Income per } \\
\text { Capita (US dollars) 2010 }\end{array}$ & $13,184^{*}$ & 10,909 & 9,501 \\
\hline
\end{tabular}

Note: * Statistically significant at the significance level $\alpha=0.01$ Source: Own elaboration based on INEGI data 2008, 2010

Table 2: Economic Concentration per Capita Index and Gross National Income per Capita.

\subsection{Households living standards}

The socio-economic development can be measured also by household facilities and equipment. In this sense it was reviewed equipment by piped water and drainage and household facilities like washing machine, fridge and solid floor. The municipality 
of Peribán shows in 2010 better conditions than state's mean in all aspects: piped water have $98.31 \%$ of the households (state's mean $92.06 \%$ ) and drainage $96.54 \%$ (state's mean $88.64 \%$ ). $79.63 \%$ of households own washing machine (state's mean $65.28 \%$ ), $86.80 \%$ own fridge (state's mean $81.88 \%$ ) and only $5.65 \%$ has earthen floor (state's mean $10.26 \%$ ). How we can observe in the figure 10, all of this characteristics are improved since 2000. In Los Reyes the development is not so uniform: only one value is higher than state's mean in 2010 (households that own washing machine) but positive development in time since 2000 was detected in case of piped water, drainage, washing machine and fridge. The share of households that has earthen floor did not reduce.

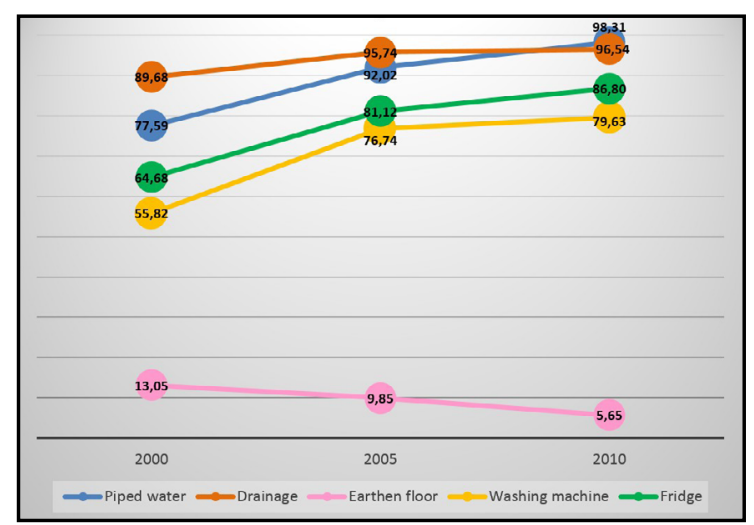

Source: Own elaboration based on INEGI data 2000, 2005, 2010

Figure 10: Household facilities and equipment, Peribán (\% of household which dispose)

\begin{tabular}{|l|c|c|c|}
\hline Indicator & $\begin{array}{c}\text { Los } \\
\text { Reyes }\end{array}$ & Peribán & $\begin{array}{c}\text { Michoacán } \\
\text { State's Mean }\end{array}$ \\
\hline $\begin{array}{l}\text { Household facilities: } \\
\text { \% of household which } \\
\text { dispose of: } \\
\text { 1. piped water }\end{array}$ & 89.45 & $98.31^{*}$ & 92.06 \\
2.drainage & 83.15 & $96.54^{*}$ & 88.64 \\
\hline $\begin{array}{l}\text { Household equipment: } \\
\text { \% of household which } \\
\text { dispose of: }\end{array}$ & & & \\
$\begin{array}{l}\text { 1. washing machine } \\
\text { 2. fridge }\end{array}$ & 68.7 & $79.63^{*}$ & 65.28 \\
3. earthen floor & 15.1 & $86.80^{*}$ & 81.88 \\
\hline
\end{tabular}

Note: * Statistically significant at the significance level $\alpha=0.01$ Source: Own elaboration based on INEGI data 2010

Table 3: Household living standards

\subsection{Women participation}

Participation of women in the labour market has a significant positive socio-economic impact. In Los Reyes work more women than state's mean
- $44.0 \%$ (compared with $32.5 \%$ state's mean, year 2010), the difference is statistically significant. In Peribán it was not identified this effect. The employment rate for both, men and women, measured by percentage of economically active persons in the total population was in 2010 of $37.69 \%$ (Los Reyes) and 37.90\% (Peribán), in both cases major than state's mean (35.27\%) and in both cases the difference is statistically significant.

\begin{tabular}{|l|c|c|c|}
\hline Indicator & Los Reyes & Peribán & $\begin{array}{c}\text { Michoacán } \\
\text { State' s Mean }\end{array}$ \\
\hline $\begin{array}{l}\text { Women } \\
\text { employment rate }\end{array}$ & $44.0^{*}$ & 31.5 & 32.5 \\
\hline $\begin{array}{l}\text { Total } \\
\text { employment rate }\end{array}$ & $37.69^{*}$ & $37.90^{*}$ & 35.27 \\
\hline
\end{tabular}

Source: Own elaboration based on INEGI data 2010

Table 4: Woman participation.

\section{Conclusion}

The prospects of the blackberry's agribusiness are positive, Mexico found its competitive advantage in this sector and it is able to exploit it. The exports of Mexican fresh berries keep growing and in the United States market of fresh berries it achieves almost 98 per cent of the total imports. Of course there is a risk of high specialization in US market. This risk can be reduced by focus to the European market or regionalization of GVCs in response to a variety of factors, including the growing importance of large emerging economies and regional trade agreements (recently signed Strategic Partnership Agreements between China and Mexico or Pacific Alliance).

The contract farming has significant benefits for both the farmers and investors. The main advantages for the small farmers consist in supplies in inputs and production services (about 25 thousands of pesos per hectare), possibility of credit through advances from the investor, introduction of new technology and also learning of new skills, reduction of farmers' price risk (contracts specify prices in advance), access to new markets which would otherwise be unavailable to small farmers. For the investors the main benefits are: working with small farmers overcomes land constraints and security of tenure of the land, less risk by not being responsible for production and more consistent quality of the product. But the farmers have to face production problems (particularly when growing new crops) and investors may be unreliable or exploit a monopoly position. 
By the HDI it is possible to compare the development level of localities, states or countries. The economic development was stronger in the case of Los Reyes; however in the social aspects (education and health) it was demonstrated a positive development in Peribán. Also the Economic Concentration per Capita is higher in Peribán.

It is known that the employment of women has a positive impact on the household equipment and facilities. The better living standards exist in Peribán: all the conditions are better than state's mean. Los Reyes has a positive development since 2000 in majority of aspects, but the difference is not statistically significant, although the women employment rate is much higher in Los Reyes. It shows the ambiguity of the social effects.

The harvest of blackberries offers jobs to the local population, especially to women, who find employment with difficulties. The job in blackberry fields represents an alternative for the young people of the Purépecha ethnicity, who otherwise tend to migrate illegally to United States.

The World Trade Organization (WTO), the OECD and the World Bank highlight that the measurement of value creation and capture is deficient in GVCs. Actually they are developing new ways to measure trade, production and employment. To capture the links between economic and social dimensions of global production and trade it is necessary grasp changing patterns because the employment data by sector are insufficient to measure jobs in diversified value chains and ignore casual jobs. In the near future it is planned to conduct a field research in Los Reyes Valley with the purpose to collect the socio-economic data and explore the phenomenon of migration.

\section{Corresponding author:}

Ing. Lucie Crespo Stupková, Ph.D.

Michoacán's College, Center of Human Geography Studies

Cerro de Nahuatzen 85, La Piedad, Michoacán, Mexico

Phone: 0052 3525256107,E-mail: lucie.stupkova@centrum.cz

\section{References}

[1] Berry B., Conkling E., Ray M.. The Global Economy in Transition (1997) "Pearson Educación", Prentice Hall, Upper Saddle River, New Jersey, ISBN 0-13—505264-5.

[2] Chollett, D. (2009) "From Sugar to Blackberries: Restructuring Agro-export Production in Michoacán, Mexico". Latin American Perspectives. Vol. 36, No. 3, pp. 79-92. doi:10.1177/0094582X09334158, ISSN 1552-678X.

[3] Eaton, C. and Shepherd, A.(2015) "Contract farming: Partnerships for Growth". 2001. FAO Agricultural Services Bulletin. [Online] Available: http://www.fao.org/docrep/014/y0937e/ y0937e00.pdf [Accessed: 7 September. 2015]. ISBN 92-5-104059-1.

[4] Gereffi, G., Fernandez-Stark K. (2011) "Global Value Chain Analysis: A Primer. Center on Globalization, Governance \& Competitiveness (CGGC)", Duke University, Durham, North Carolina, USA, [Online] Available: http://www.cggc.duke.edu/pdfs/2011-05-31_GVC_analysis_a_ primer.pdf [Accessed: 23 August, 2015].

[5] Haggblade S., Theriault V., Staatz J., Dembele N. and Diallo B. (2012) "A Conceptual Framework for Promoting Inclusive Agricultural Value Chains". Michigan State University Department of Agricultural, Food and Resource Economics. [Online] Available: http://fsg.afre.msu.edu/IFADWA/conceptual_framework.pdf. [Accessed: 7 September. 2015].

[6] Humphrey, J. and Schmitz, H. (2000) "Governance and Upgrading: Linking Industrial Cluster and Global Value Chain". IDS Working Paper 120, Institute of Development Studies, University of Sussex, Brighton. ISBN 1858643341.

[7] ITC (International Trade Center).(2015) List of exporters for the selected product 081020. Trade Map. Trade statistics for international business development. [Online] Available: http://www. trademap.org/\%28X\%281\%29S\%28utisqj55wugzyr55e20tagnp\%29\%29/Country_SelProduct_ TS.aspx [Accessed: 8 July. 2015]. 
[8] Knox, P. and Agnew, J. (2002) "The Geography of the World Economy", Oxford University Press Inc., New York, ISBN 0340706120.

[9] Lee, J. and Gereffi, G. (2015) "Global Value Chains, Rising Power Firms and Economic and Social Upgrading", Critical Perspectives on International Business, Vol. 11, No. (3/4), pp. 319-339. ISSN 1742-2043, doi: 10.1108/cpoib-03-2014-0018 .

[10] Lee J., Gereffi G. and Barrientos S. (2011) "Global value chains, upgrading and poverty reduction. Capturing the Gains - Economic and Social Upgrading", Briefing note 3 - November 2011. [Online] Available: http://www.capturingthegains.org/pdf/ctg_briefing_note_3.pdf Accessed: [Accessed: 15 September. 2015].

[11] Maertens, M. and Swinnen, J. F. M. (2009) "Trade, standards, and poverty: Evidence from Senegal". World Development, Vol. 37, No. 1, pp. 161-78. ISSN: 0305-750X.

[12] Morales, C. and Sánchez, M. (2012) "Competitividad internacional de agronegocios: el caso de la zarzamora mexicana". ALAFEC, [Online] Available: http://www.morales-troncoso.com/doc/ pdf/alafec2012.pdf [Accessed: 23 July. 2015].

[13] Nadvi, K. (2014) "Rising Powers' and labour and environmental standards". Oxford Development Studies, Vol. 42, No. 2, pp. 137-50. ISSN 1469-9966.

[14] National Institute of Geography and Statistics (NIGS) (2010, 2005, 2000) Services and goods in households, Housing characteristics, 2010, 2005, 2000. Employment rate. Women employment rate. 2010, 2005, 2000. [Online] Available: http://www3.inegi.org.mx/sistemas/temas/default. aspx?s=est\&c=17484 [Accessed: 20 November. 2015].

[15] National Institute of Geography and Statistics (NIGS) (2015) Balance of trade of Mexico. [Online] Available: http://www.inegi.org.mx/prod_serv/contenidos/espanol/bvinegi/productos/continuas/ economicas/exterior/mensual/ece/bcmm.pdf [Accessed: 23 September. 2015].

[16] OECD, WTO and World Bank Group.(2014) Global Value Chains: Challenges, Opportunities, and Implications for Policy. [Online] Available: http://www.oecd.org/tad/gvc_report_g20_july_2014. pdf [Accessed: 2 September. 2015].

[17] OECD/WTO (2014). Aid for Trade 2011: Results Emerging From the Case Stories, OECD/WTO, Paris and Geneva in OECD, WTO and World Bank Group. Global Value Chains: Challenges, Opportunities, and Implications for Policy. [Online] Available: http://www.oecd.org/tad/gvc_report_ g20_july_2014.pdf [Accessed: 2 September. 2015].

[18] Palacio-Prieto, J. L., Sanchéz-Salazar, M. T., Casado-Ozquerdo, J. M., Propin Frejomil, E., Delgado Campos, J., Velázquez Montes, A., Chias Becerril, L., Ortiz Álvarez, M. I., González Sánches, J., Negrete Fernández, G., Gabriel Morales, J., Márquez Huitzil, R. (2004) "Indicadores para $l$ a caracterización y el ordenamiento territorial". Universidad Nacional Autónoma de México. [Online] Available: https://books.google.com.mx/books?id=_kvT8mQKH_QC\&pg=PA11\&lpg=PA11\&dq [Accessed: 11 September. 2015]. ISBN 970-32-1885-7.

[19] Pye-Smith, Ch. (2013) "Policy Pointer: Value Chains for transforming smallholder agriculture". Technical Centre for Agricultural and Rural Cooperation. Wageningen, Netherlands. ISBN 2212-6333.

[20] Sánchez, G. (2008) "La red de valor de la zarzamora, El cluster de Los Reyes, Michoacán: Un ejemplo de reconversión competitiva." Morelia: Fundación Produce Michoacán. Serie: Sistema de Inteligencia de Mercados para Desarrollo Competitivo del Sector Agropecuario del Estado de Michoacán, Vol. 6. [Online] Available: www.siac.org.mx/tecnos/14mich.pdf [Accessed: 27 July. 2015].

[21] SIAP (Agricultural and Fishery Information Service) (2014) Anual Production of Blackberry SAGARPA (Department of Agriculture, Rural Development, Fishery and Alimentation). [Online] Available: http://www.siap.gob.mx/cierre-de-la-produccion-agricola-por-estado/. [Accessed: 7 September. 2015]. 
[22] STPS (Department of Labor and Social Welfare) (2015) Minimum wages, National Commission on Minimum Wages, April 2015. [Online] Available: http://www.conasami.gob.mx/boletin_nvos sal_abril_2015.html. [Accessed: 8 September. 2015].

[23] Thiébaut, V. (2011) "Rural Landscape and Export Crops. Valle de Los Reyes, Michoacán". Trayectorias año 13, enero-junio 2011, No. 32, pp. 52-70. ISSN 2007-1205.

[24] Thiébaut, V. (2012) "La transformation des paysages agraires mexicains. Cultures de la canne à sucre et de la mûre dans la vallée de Los Reyes, Michoacán", Cybergeo: European Journal of Geography (Online), Environment, Nature, Landscape, [Online] Available: http://cybergeo.revues.org/25615?lang=en [Accessed: 10 September 2015]. ISSN 1278-3366. DOI: $10.4000 /$ cybergeo.25615.

[25] Thiébaut, V. (2009) "De la caña a la zarzamora". Estudios Michoacanos XIII. Colegio de Michoacán, A. C. ISBN 978-607-7764-15-1.

[26] Tsigas, M. and Ferrantino M.. (2014) "Modeling the Benefits of Trade Facilitation for the G20, USITC Working Paper, Washington D.C. in OECD, WTO and World Bank Group. Global Value Chains: Challenges, Opportunities, and Implications for Policy. [Online] Available: http://www. oecd.org/tad/gvc_report_g20_july_2014.pdf [Accessed: 2 September. 2015].

[27] UNCTD (United Nations Conference on Trade and Development) (2013) "Global value chains and development". [Online] Available: http://unctad.org/en/PublicationsLibrary/diae2013d1_en.pdf [Accessed: 27 August. 2015].

[28] UNCTD (United Nations Conference on Trade and Development) (2013) "World Investment Report", Global Value Chains: Investment and Trade for Development. 236 p. [Online] Available: http://unctad.org/en/pages/PublicationWebflyer.aspx?publicationid=588 [Accessed: 20 August. 2015]. ISBN 978-92-1-112868-0

[29] Webber, M. and Labaste, P. (2010) "Building Competitiveness in Africa's Agriculture: A Guide to Value Chain Concepts and Application", Agriculture and Rural Development. The International Bank for Reconstruction and Development. The World Bank. [Online] Available https://openknowledge.worldbank.org/handle/10986/2401 [Accessed: 12 August. 2015] ISBN: 978-0-8213-7952-3

[30] Wiggins S. (2013) "African agriculture in a changing global context: lessons learned", Overseas Development Institute. Brussels Policy Briefing no. 33. [Online] Available: https://brusselsbriefings. files.wordpress.com/2013/10/br33_steve_wiggins.pdf. [Accessed: 7 September. 2015]. 